\title{
The Chabrières Tunnel, Alpes-de-Haute-Provence, France
}

Dr David Giles*, School of Earth and Environmental Sciences, Burnaby Building, University of Portsmouth, Burnaby Road, Portsmouth PO1 3QL

dave.giles@port.ac.uk

* Corresponding author

\section{Contents}

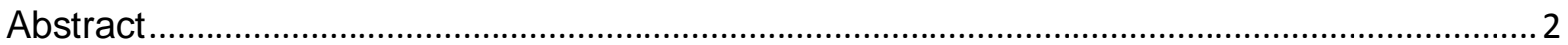

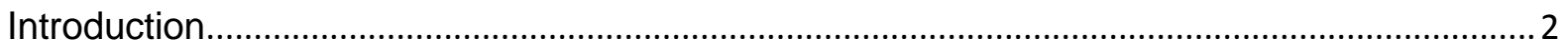

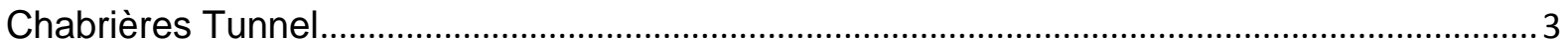

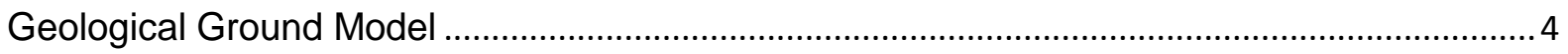

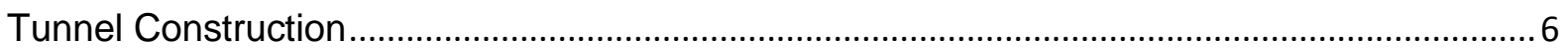

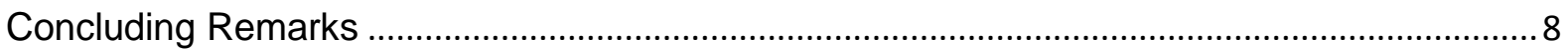

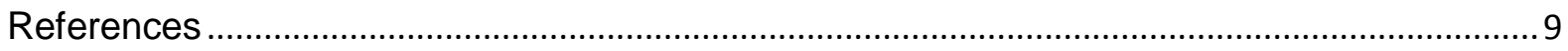

Figure 1 Completion of the Tunnel de Chabrières, Alpes de Haute Provence, France, 2014. Tunnel with rock fall shelter through steeply dipping limestone with further rock bolts and rock catch nets protecting the tunnel portal. Part of the ongoing rock slope stability improvements to the RN85 (Image taken 2014).

Figure 2 Site location map, Chabrières, Alpes-de-Haute-Provence, France.............................. 3

Figure 3 Limestone gorge through Tithonian and Oxfordian limestones and marls at the Clue de Chabrières, Alpes-de-Haute-Provence, France (Image taken 2005) ................................... 3

Figure 4 Simplified geological map of the Chabrières area (After Ganeval 1973, Polo

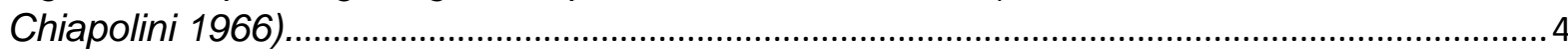

Figure 5 Generalised stratigraphic column of Jurassic and Cretaceous rocks of the Vocontian domain (After Hobléa 2014, Ferry 2017).............................................................. 4 Figure 6 Tunnel outline in the Middle Oxfordian limestone and marl interbeds at the southern portal (Image taken 2013, S. Thébault) ................................................................................ Figure 7 Thrusting in evidence within the massive and bedded Tithonian limestone at the tunnel northern portal.

Figure 8 Tunnel profile summarising geological and geotechnical variability along the tunnel alignment (Adopted and translated from Rabier et al. 2015, Peru \& Panigoni 2015)................ 5

Figure 9 The northern portal site in 2005 (left) and post construction in 2014 (right). ............. 6 Figure 10 Tunnel de Chabrières northern portal excavated through mainly massive Tithonian limestones (Image taken 2014).

Figure 11 Anchored rock catch nets at the southern tunnel portal protecting the carriageway from rock falls generated within the interbedded limestone and marls of the Middle Oxfordian (Image taken 2005). 
Figure 12 Various generations of dental masonry mitigating rock and debris fall from the more heavily Middle Oxfordian interbedded zones in vicinity of the southern tunnel portal.....7 Figure 13 Previous slope stabilisation works with rock bolting and rock netting being installed at the northern end of the Clue de Chabrières (Image taken 2005).

Figure 14 The nature of the site presented challenging engineering conditions for the installation of the rock bolts and rock catch net anchors (Image taken 2005)...

Figure 15 Rock bolts utilised for the rock mass support and protection measures.................. 8 Figure 16 Rock avalanche shelter constructed at the northern tunnel portal (Image taken 2014).

\section{Abstract}

In 2017, the Quarterly Journal of Engineering Geology and Hydrogeology celebrated its $50^{\text {th }}$ anniversary. The cover image chosen for this anniversary year was of the northern portal of the Chabrières Tunnel, Alpes-de-Haute-Provence, France. The tunnel had been recently excavated through steeply dipping Jurassic limestones and marls using drill and blast methods. This paper provides more context to the engineering geology and construction of this tunnel with details of the geological ground conditions and developed ground model.

Figure 1 Completion of the Tunnel de Chabrières, Alpes de Haute Provence, France, 2014. Tunnel with rock fall shelter through steeply dipping limestone with further rock bolts and rock catch nets protecting the tunnel portal. Part of the ongoing rock slope stability improvements to the RN85 (Image taken 2014).

\section{Introduction}

In 2017, the Quarterly Journal of Engineering Geology and Hydrogeology (QJEGH) celebrated its $50^{\text {th }}$ anniversary. The cover image chosen for the journal in this golden year was that of the construction of a tunnel near to Chabrières on the RN85 (Route Napoleon) in the Alpes-de-Haute-Provence, France (Fig 1). The tunnel was constructed through steeply dipping limestone, often thrusted, with the tunnel portal 
protected by a rock fall shelter, substantial rock bolting and further rock catch nets. The project was part of ongoing road and slope stability improvements upgrading the RN85 through this section. This paper provides more background and context to this case study and anniversary issue front cover.

Figure 2 Site location map, Chabrières, Alpes-de-Haute-Provence, France.

\section{Chabrières Tunnel}

The 180m long Chabrières tunnel is located on the RN85 Digne to Nice link road in the Alpes-de-Haute-Provence, France (Fig 2). A section of this route passed through a very narrow limestone gorge at the Clue de Chabrières (Fig 3). The carriageway at this section was extremely narrow, only $6 \mathrm{~m}$ in places, and had to negotiate a large overhanging limestone abutment on one side with the gorge and fast flowing River Asse on the other (DREAL Paca 2015a). This section of road presented other hazards including rock and debris falls from the steep, near vertical, rock face above. To improve traffic flow and increase overall road safety, a tunnel was constructed cutting out the Clue bottleneck (Rabier et al. 2015). The initial studies for the project took place in 1994 with ground investigation work carried out in 2009. Work commenced on the tunnel in 2013 with it finally opening in July 2015 (DREAL Paca 2015b). The overall cost of the project was $€ 12.6 \mathrm{M}$ with $€ 12 \mathrm{M}$ of construction costs, $€ 550 \mathrm{k}$ investigation costs with the remainder being land acquisition (DREAL Paca 2015c). 


\section{Geological Ground Model}

Chabrières is located in the foothills of the western Alps in the tectonic unit of the Southern Subalpine Chains (Ford \& Lickorish 2004, Hobléa 2014) (Fig 4) and is located in the international Geopak of Haute-Provence (Pagès 2009). The constructed tunnel cuts through limestone and marls of Upper Jurassic (Tithonian, Kimmeridgian and Oxfordian) age and lies close to the Digne Thrust System with a major splay from this belt located between Chabrières and Chateauredon (Graham et al. 2012). The Tithonian (British Portlandian equivalent) strata has a calcareous facies zoned via a cephalopod (ammonite) fauna. Deposited in the Vocontian Trough in the northern, sub Mediterranean province of the Tethys Ocean, the strata have been heavily structurally deformed with numerous thrusts and folds being present. The Tithonian strata are white fine grained limestones, generally massive with beds thicknesses ranging from several meters to around $0.2 \mathrm{~m}$. The Kimmeridgian and Oxfordian aged rocks are again dominated by light fine grained limestones, are more thinly bedded around $0.2 \mathrm{~m}$ to 1.0m thick, occasionally becoming more interbedded with marls (Ferry 2017, Rabier et al. 2015).

Figure 4 Simplified geological map of the Chabrières area (After Ganeval 1973, Polo Chiapolini 1966).

Figure 5 Generalised stratigraphic column of Jurassic and Cretaceous rocks of the Vocontian domain (After Hobléa 2014, Ferry 2017).

The tunnel cuts through the northern flank of an east-west trending anticline with beds dipping between $45^{\circ}$ and $60^{\circ}$ to the north. Thrusting is in evidence at the northern 
tunnel portal (Fig 5). Together with bedding, there are 2 additional distinct discontinuity sets orthogonal to each other. One set has a sub vertical dip and a dip direction parallel to the tunnel alignment. Some minor karstic zones and areas of higher permeability were also present along the alignment within more heavily fractured zones.

Figure 6 Tunnel outline in the Middle Oxfordian limestone and marl interbeds at the southern portal (Image taken 2013, S. Thébault).

Figure 7 Thrusting in evidence within the massive and bedded Tithonian limestone at the tunnel northern portal.

Geotechnically the lithological units were characterised as 2 separate domains based on their Rock Mass Ratings (RMR) giving 2 distinct rock classes (Rabier et al. 2015). Geomechanical Zone I contained rock with limited fracturing with a characteristic Rock Class of Good Rock (II) to Good (II) to Fair Rock (III) based on the RMR assessment (Bienawski 1989). This zone covered $70 \%$ of the tunnel chainage. Geomechanical Zone II characteristically had Fair (III) to Poor Rock (IV) in places for the other $30 \%$ of the tunnel chainage. Rock material strengths (UCS) ranged from 50MPa (Strong) to 200MPa (Very Strong). Figure 6 details the tunnel profile with the geological model and geomechanical classifications (Rabier et al. 2015, Peru \& Panigoni 2015).

Figure 8 Tunnel profile summarising geological and geotechnical variability along the tunnel alignment (Adopted and translated from Rabier et al. 2015, Peru \& Panigoni 2015). 


\section{Tunnel Construction}

The tunnel was excavated from north to south with the limestone and marl beds adversely dipping into the excavation (Fig 7). The generally good quality of the rock mass enabled drill and blast techniques to be used for the excavation method despite the potential of some karstic areas and more highly fractured zones being present. A total of 64 blasts were required to complete the excavation. Due to the sensitivity of the adjacent Digne to Nice railway line, the site was instrumented and the blasting heavily monitored (DREAL Paca (2015a). The excavation was supported with either shotcrete or steel arches with 3 support methodologies utilised (Rabier et al. 2015):

1. Non-fibre reinforced shotcrete on tunnel walls in combination with radial bolting with 2-6 bolts per meter.

2. Fibre reinforced shotcrete on tunnel face and walls with radial bolting with 6-10 bolts per meter.

3. Fibre reinforced shotcrete on tunnel face and walls in association with a heavy duty HEB steel arch filled with non-fibre reinforced shotcrete at the tunnel portals.

On construction, the ground conditions were as expected with the first support system being the most utilised along the length of the tunnel drive.

Figure 9 The northern portal site in 2005 (left) and post construction in 2014 (right).

The main concerns with the tunnel construction were around the 2 portal areas (Fig 8). Rock slope stability issues above the portal zones had to be mitigated both during 
initial works and on tunnel construction. Potential problems resulting from blasting generated vibrations on the rock mass potential initiating rock falls and rock slides were dealt with by a series of rock bolts along with rock catch nets. The adverse dip of the limestone beds along with heavily weathered loose material on the overhead slopes also had to be dealt with.

Figure 10 Tunnel de Chabrières northern portal excavated through mainly massive Tithonian limestones (Image taken 2014).

Previous works had installed a series of rock protection measures around the Clue with rock catch nets (Fig 9) and various generations of dental masonry (Fig 10). The installation of the rock bolts and anchors for the rock catch nets was a challenging technical process given the morphology of the slope and access issues (Fig 11 and 12), particularly with the size of bolts/anchors used (Fig 13). The northern portal was particularly problematic requiring the construction of a rock avalanche shelter (Fig 14) together with a rock trap ditch to protect this section of the carriageway. Additional bolts and anchors were also installed across the portal crown.

Figure 11 Anchored rock catch nets at the southern tunnel portal protecting the carriageway from rock falls generated within the interbedded limestone and marls of the Middle Oxfordian (Image taken 2005).

Figure 12 Various generations of dental masonry mitigating rock and debris fall from the more heavily Middle Oxfordian interbedded zones in vicinity of the southern tunnel portal. 
Figure 13 Previous slope stabilisation works with rock bolting and rock netting being installed at the northern end of the Clue de Chabrières (Image taken 2005).

Figure 14 The nature of the site presented challenging engineering conditions for the installation of the rock bolts and rock catch net anchors (Image taken 2005).

Figure 15 Rock bolts utilised for the rock mass support and protection measures.

Figure 16 Rock avalanche shelter constructed at the northern tunnel portal (Image taken 2014).

\section{Concluding Remarks}

The Tunnel de Chabrières presents an excellent case study detailing the complexities of geology to be assessed and mitigated by engineering geologists during a construction project. Steeply dipping limestone beds with occasional marls and heavily fractured zones in a thrusted and folded terrain present challenging geological conditions for the tunnel and approach road. The engineering construction utilised rock slope support and protection methods together with a rock avalanche shelter to protect the tunnel portal. The anniversary photograph chosen for the QJEGH front cover perfectly illustrates all of these interacting parameters that benefit from a welldeveloped ground model with engineering geological input 


\section{References}

Bienawski, Z. T. (1989). Engineering Rock Mass Classifications: A Complete Manual for Engineers and Geologists in Mining, Civil, and Petroleum Engineering. Wiley, Chichester.

DREAL Paca (2015a). Exposition du Projet Chabrières- DREAL Paca. Retrieved from http://www.paca.developpementdurable.gouv.fr/lMG/pdf/Chabrieres Expo Projet f.pdf

DREAL Paca (2015b). RN85 Tunnel de Chabrières. Direction régionale de l'environnement, de l'aménagement et du logement (DREAL), Provence Alpes Cote d'Azur (Paca). Retrieved from http://www.paca.developpementdurable.gouv.fr/IMG/pdf/04-20150622-GP-Chabrieres-V3bis.pdf

DREAL Paca (2015c). Tunnel de Chabrières - DREAL Paca. Retrieved from http://www.paca.developpementdurable.gouv.fr/IMG/pdf/2015 05 PlaquetteChabrieres 12P j.pdf

Ferry, S. (2017). Summary on Mesozoic carbonate deposits of the Vocontian Trough (Sub-alpine Chains, SE France). Some key Lower Cretaceous sites in Drôme (SE France). Carnets de Géologie, Madrid, CG2017_B01, ISBN, 978-2.

Ford, M. \& Lickorish, W. H. (2004). Foreland basin evolution around the western Alpine Arc. From: Joseph, P. \& Lomas, S. A. (eds). Deep-Water Sedimentation in 
the Alpine Basin of SE France: New perspectives on the Gres d'Annot and related systems. Geological Society, London, Special Publications, 221, 39-63.

Ganeval, J. (1973). Paléogéographie et tectonique dans la zone de d'enrochement de Creisset-Le Poil (Branche nord-ouest de l'Arc de Castellane, Alpes de Haute Provence), Alpes françaises Tectonique. Université Scientifique et Médicale de Grenoble, Français.

Graham, R., Jackson, M., Pilcher, R., \& Kilsdonk, B. (2012). Allochthonous salt in the sub-Alpine fold-thrust belt of Haute Provence, France. From: Alsop, G. I., Archer, S. G., Hartley, A. J., Grant, N. T. \& Hodgkinson, R. (eds). Salt Tectonics, Sediments and Prospectively. Geological Society, London, Special Publications, 363, 595-615. doi.org/10.1144/SP363.30

Hobléa, F. (2014). In the folds of the earth: French prealpine geomorphological landscapes. In Landscapes and landforms of France, 183-194. Springer Netherlands.

Pagès, J. S. (2009). The GeoPark of Haute-Provence, France—geology and palaeontology protected for sustainable development. PaleoParks-the protection and conservation of fossil sites worldwide. Carnets de Géologie / Notebooks on Geology, Book, 3. DOI: 10.4267/2042/34556

Peru, Y. \& Panigoni, T. (2015). Retour d'expérience du suivi des vibrations lors $d u$ creusement à l'explosif du tunnel de Chabrières. Journees Techniques Acoustique et 
Vibrations, Nantes. Retrieved from

http://jtav.ifsttar.fr/fileadmin/contributeurs/JTAV/2015/JTAV CETU Y PERU.pdf

Polo Chiapolini, C. (1966). Contribution à l'étude géologique de la région de Chabrières (Basses Alpeds) Feuille au 1/25 000: Digne 1-2, 3-4, 5-6, 7-8.

Stratigraphie. Université Scientifique et Médicale de Grenoble, Français.

Rabier, M., Peru, Y. \& Serratrice, J-F. (2015). Génie civil du tunnel de Chabrières dans les Alpes-de-Haute-Provence. Tunnels et Espace Souterrain, 248, 109-118. 


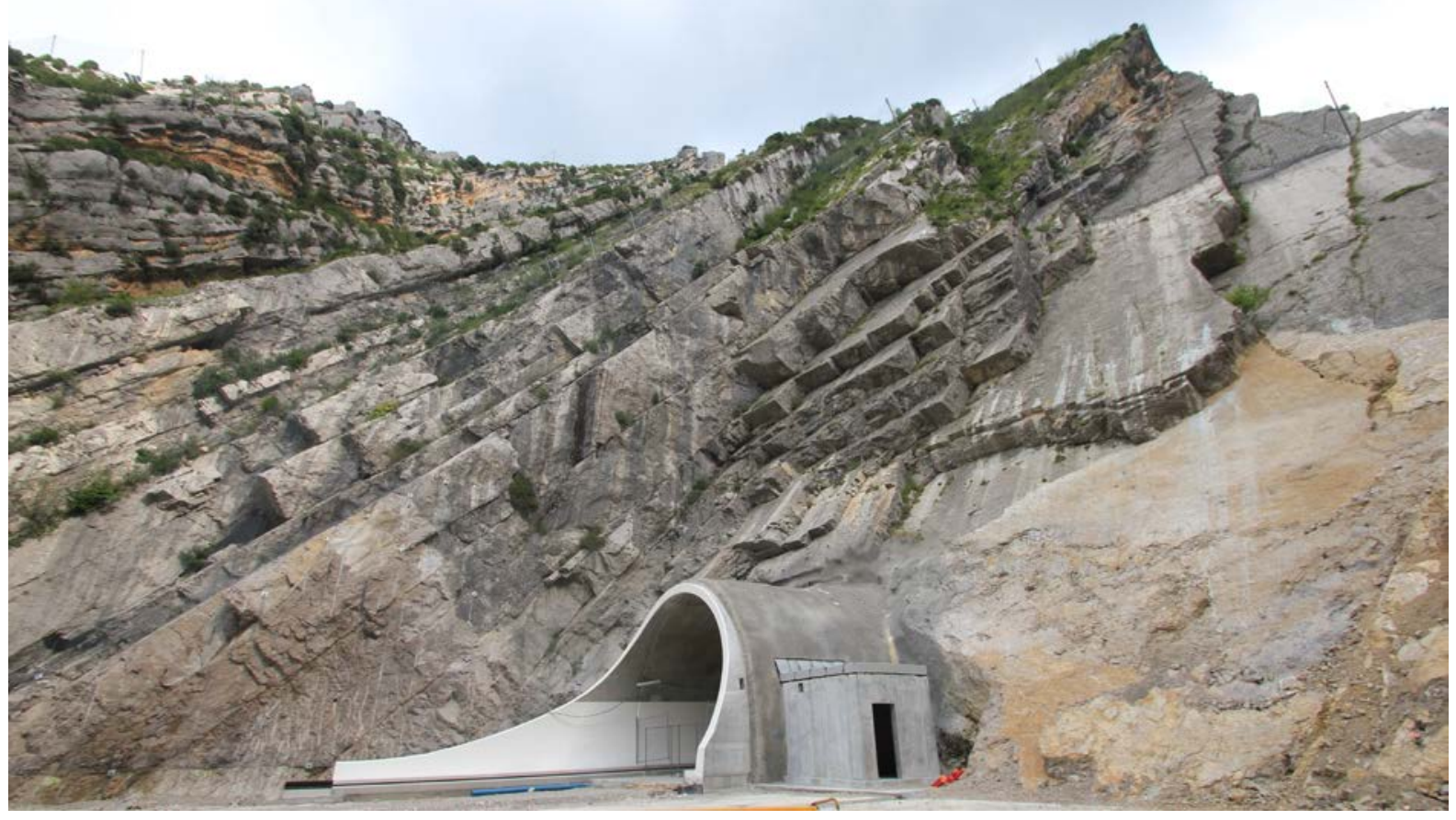

Figure 1 Completion of the Tunnel de Chabrières, Alpes de Haute Provence, France, 2014. Tunnel with rock fall shelter through steeply dipping limestone with further rock bolts and rock catch nets protecting the tunnel portal. Part of the ongoing rock slope stability improvements to the RN85 / D4085 (Image taken 2014). 

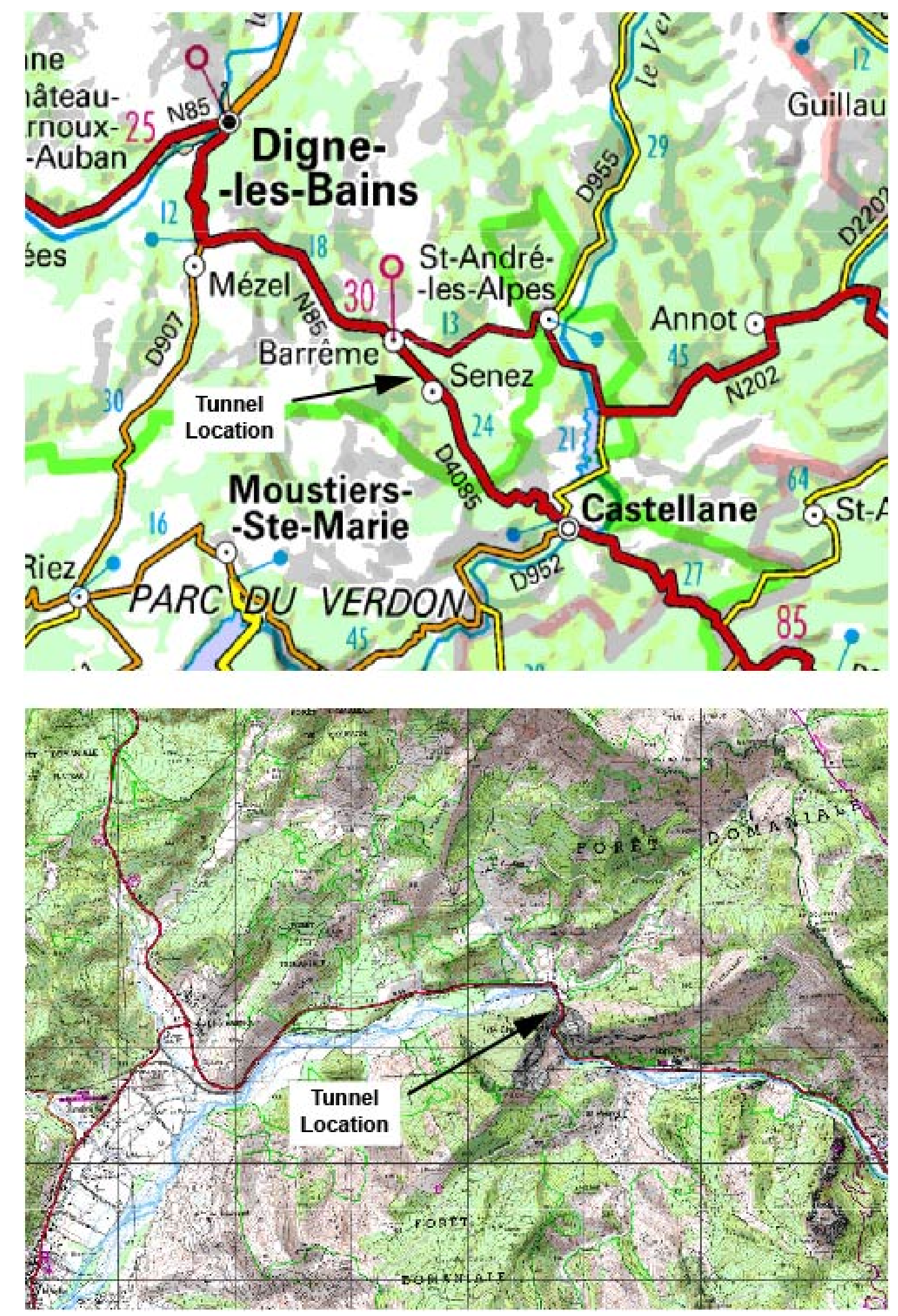

Figure 2 Site location map, Chabrières, Alpes-de-Haute-Provence, France 
Figure 3 Limestone gorge through Tithonian and Oxfordian limestones and marls at the Clue de Chabrières, Alpes-de-Haute-Provence, France (Image taken 2005). 

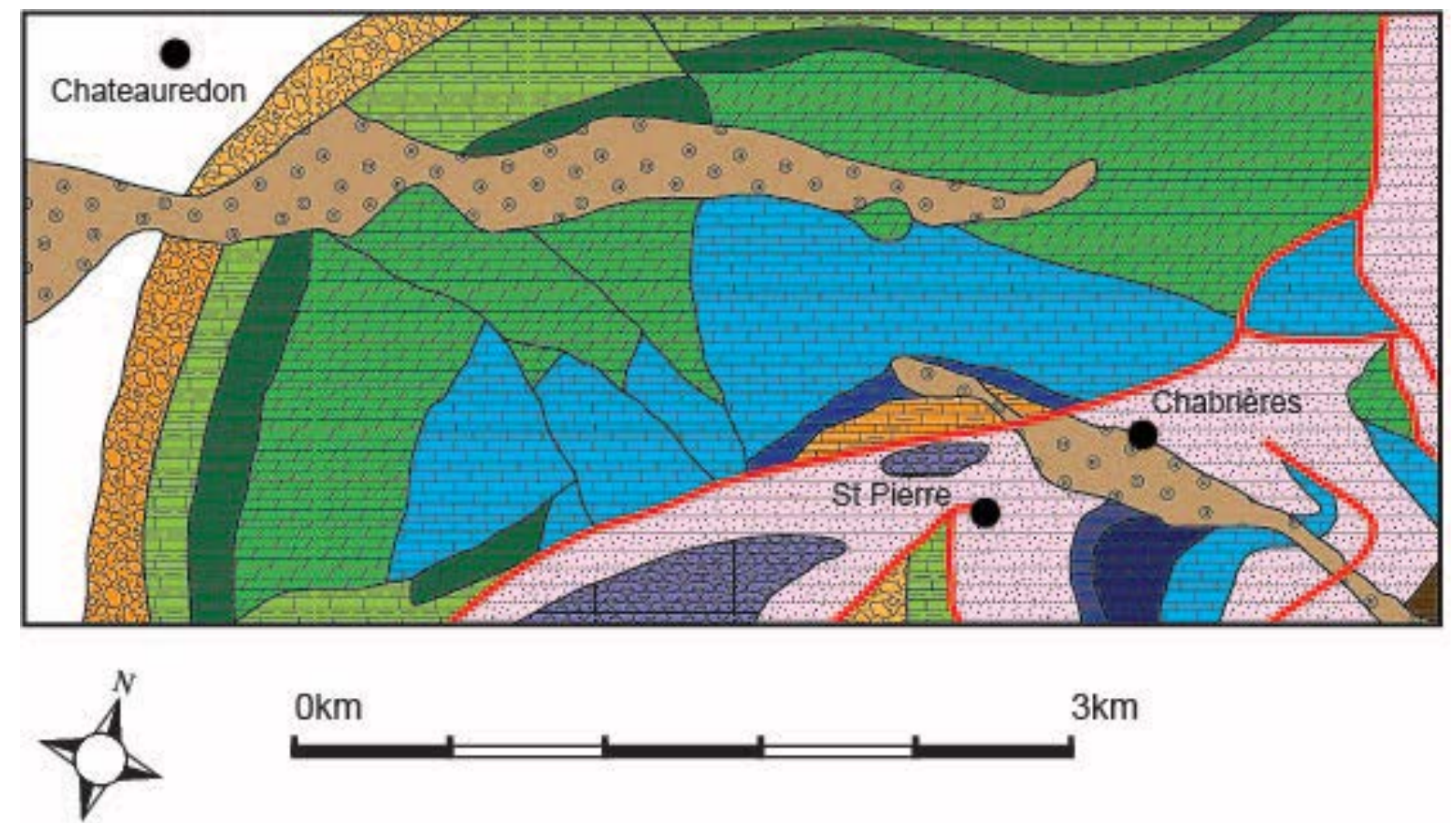

\begin{tabular}{|c|c|}
\hline Alluvium & Upper Oxfordian (Argovian) \\
\hline Miocene & Lower Oxfordian (Terres Noires) \\
\hline Cenomanian, Albian, Aptian & Lias \& Dogger \\
\hline Barremian & Upper Trias - Keuper \& Rhaetian \\
\hline Berriasian & Middle Trias - Muscelchalk \\
\hline
\end{tabular}

Figure 4 Simplified geological map of the Chabrières area (After Ganeval 1973, Polo Chiapolini 1966). 


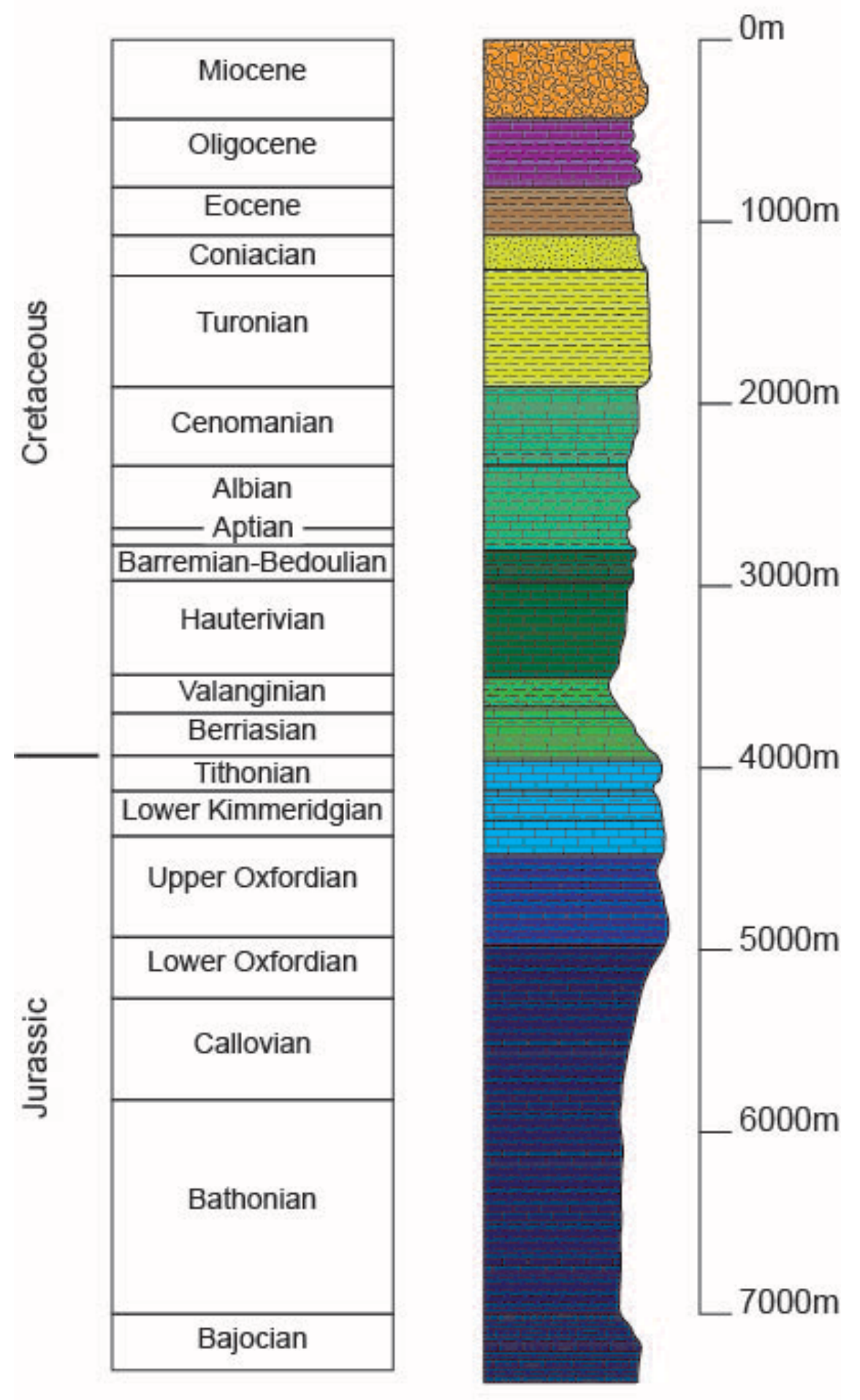

Figure 5 Generalised stratigraphic column of Jurassic and Cretaceous rocks of the Vocontian domain (After Hobléa 2014, Ferry 2017). 


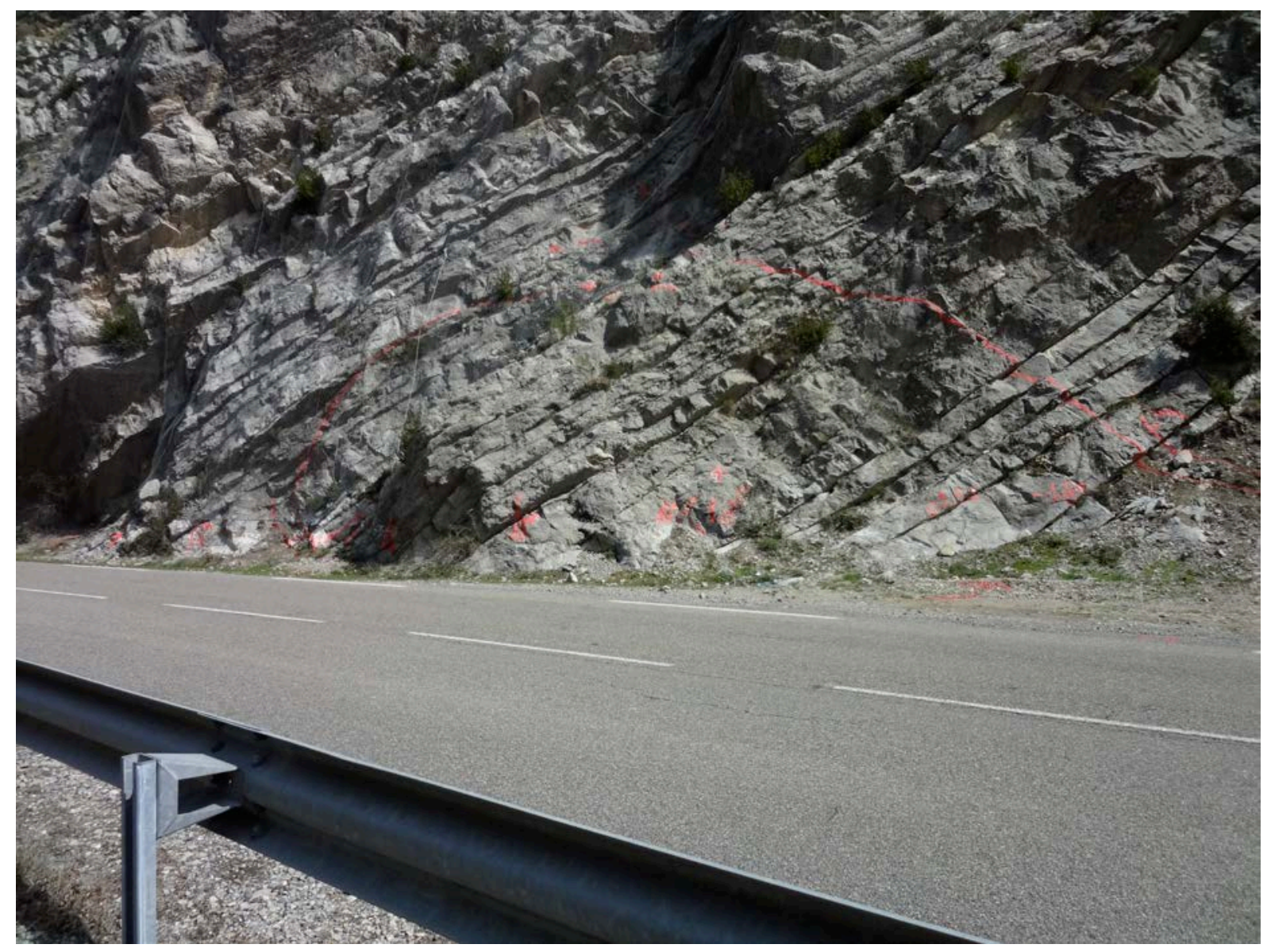

Figure 6 Tunnel outline in the Middle Oxfordian limestone and marl interbeds at the southern portal (Image taken 2013, S. Thébault). 
Figure 7 Thrusting in evidence within the massive and bedded Tithonian limestone at the tunnel northern portal. 


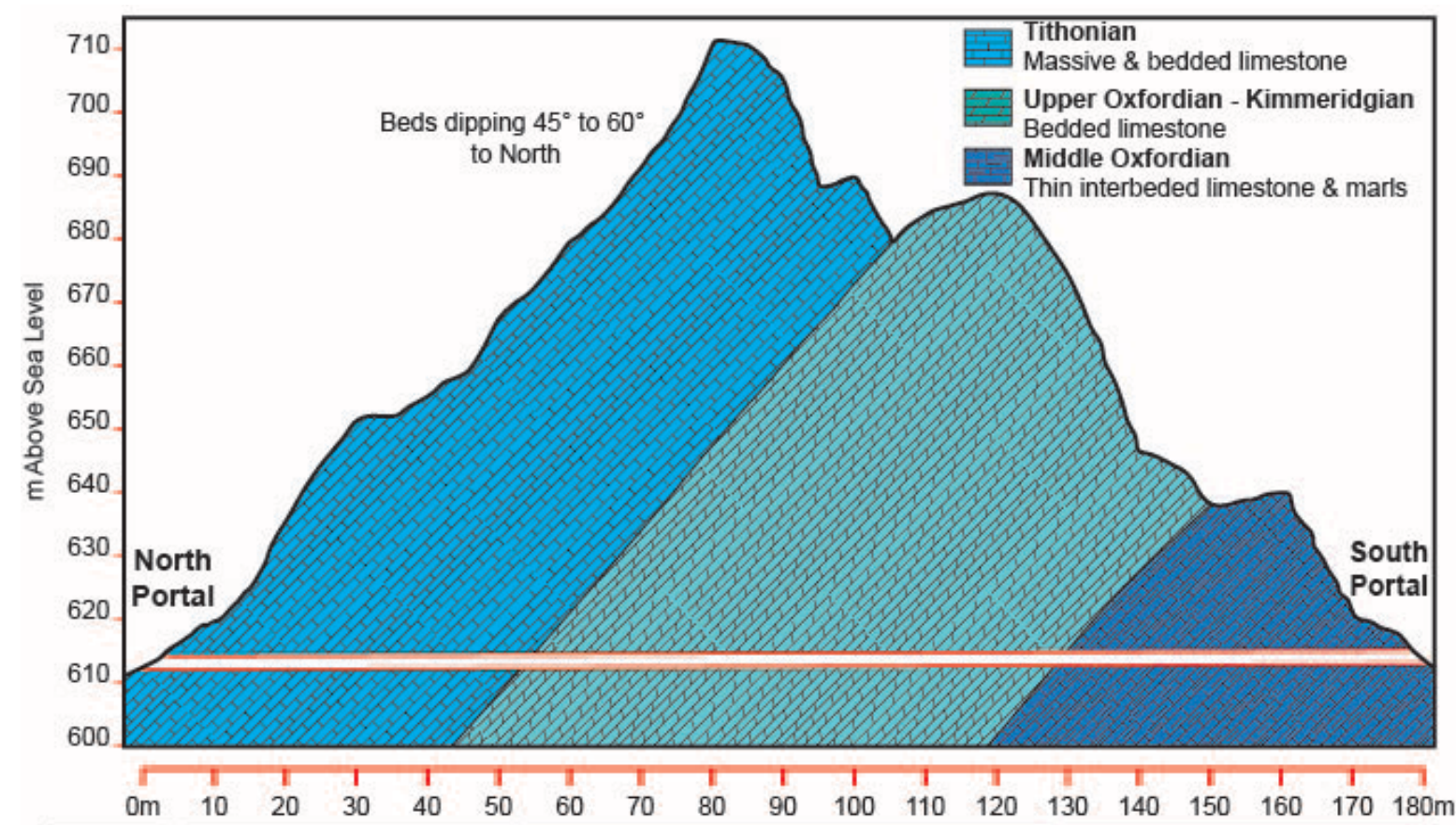

\begin{tabular}{|c|c|c|c|c|c|c|c|}
\hline Geology & \multicolumn{3}{|c|}{ Tithonian } & \multicolumn{2}{|c|}{ Upper Oxfordian - Kimmeridgian } & \multicolumn{2}{|c|}{ Miodle Oxforc an } \\
\hline Lithology & \multicolumn{3}{|c|}{ Massive $\&$ bedded limestone } & \multicolumn{2}{|c|}{ Bedded limestone } & \multicolumn{2}{|c|}{ Thin interbeded limestone \& marls } \\
\hline ucs & \multicolumn{7}{|c|}{ Uniaxial Compressive Strengths $50 \mathrm{MPa}$ to $200 \mathrm{MPa}$} \\
\hline RMR Class & RMR III & RMR ॥ & RMR III & RMR II & RMR III & RMR ॥ & RMR III \\
\hline $\begin{array}{l}\text { Geomech } \\
\text { Zone }\end{array}$ & $\mathrm{z} 2$ & $\mathrm{z} 1$ & $\mathrm{z} 2$ & $\mathrm{z} 1$ & $\mathrm{z} 2$ & $\mathrm{z}_{1}$ & $\mathrm{z} 2$ \\
\hline
\end{tabular}

Figure 8 Tunnel profile summarising geological and geotechnical variability along the tunnel alignment (Adopted and translated from Rabier et al. 2015, Peru \& Panigoni 2015). 
Figure 9 The northern portal site in 2005 (left) and post construction in 2014 (right).

Figure 10 Tunnel de Chabrières northern portal excavated through mainly massive Tithonian limestones (Image taken 2014). 
Figure 11 Anchored rock catch nets at the southern tunnel portal protecting the carriageway from rock falls generated within the interbedded limestone and marls of the Middle Oxfordian (Image taken 2005). 
Figure 12 Various generations of dental masonry mitigating rock and debris fall from the more heavily Middle Oxfordian interbedded zones in vicinity of the southern tunnel portal. 
Figure 13 Previous slope stabilisation works with rock bolting and rock netting being installed at the northern end of the Clue de Chabrières (Image taken 2005).

Error! Bookmark not defined. 
Figure 14 The nature of the site presented challenging engineering conditions for the installation of the rock bolts (Image taken 2005). 
Figure 15 Rock bolts utilised for the rock mass support and protection measures. 
Figure 16 Rock avalanche shelter constructed at the northern tunnel portal (Image taken 2014). 